\title{
UNIÃO ESTÁVEL. ANTIGA FORMA DE CASAMENTO DE FATO
}

\author{
Álvaro Villaça Azevedo \\ Diretor da Faculdade de Direito da USP \\ Professor Titular do Departamento de Direito Civil da FDUSP \\ Professor Titular de Direito Civil e Romano da Faculdade \\ de Direito da Universidade Mackenzie
}

Resumo:

O casamento consistia, em épocas antigas, na celebração religiosa ou em ato decorrente do próprio interesse das partes, sem nenhuma participação do Estado.

$\mathrm{Na}$ lei romana existia, particularmente, o casamento com a celebração de caráter religioso ("confarreatio"), o casamento pela compra simulada da mulher ("coemptio"), o casamento pelo direito comum, pela posse continuada ("usus"), o concubinato, tendo importância a vida familiar como marido e mulher, sem casamento ("concubinatus") e o casamento entre escravos ("contubernium").

Resquícios destas configurações da constituição familiar chegaram até a Idade Média, alcançando a lei brasileira, pelas Ordenações do Reino de Portugal, especialmente pelas Ordenações Filipinas, de 1603. Nestas havia: a. o casamento religioso; b. o casamento clandestino (secreto), também conhecido como casamento do direito comum ou chamado casamento dos conhuçudos, no qual a estabilidade da vida familiar entre o homem e a mulher, que constituíam a família, levava-os à condição de casados; e c. o casamento por escritura pública, perante duas testemunhas.

Com a edição, entre nós, do Decreto n. 181, de 1890, que estabeleceu o casamento civil, com formalidades severas, aproximadamente há mais de cem anos atrás, as outras formas de constituição de família, que eram aceitas pela sociedade brasileira, passaram a não mais ser admitidas pelo Governo.

Também, como o divórcio era proibido, sendo-o até o advento da Lei n. 6.515, de 27.12.77, aqueles que se judicialmente (àquela época chamados "desquitados") viviam em concubinato puro, isto é, nem adulterino nem incestuoso.

O casamento de fato era o que hoje chamamos de concubinato puro, como visto, e ainda havia o concubinato impuro (incestuoso ou adulterino) que tinha sido sempre condenado. Desde então, o sentido pejorativo da palavra concubinato foi extinto, gradualmente, entre nós, como uma reconquista, pelo nosso povo, do antigo casamento de fato. Essa forma de casamento persiste em vários outros países como "casamento de direito comum" em quatorze Estados norte-americanos; na Escócia, com o mesmo nome; e no Estado mexicano de Tamaulipas - casamento por comportamento.

A Constituição Federal brasileira, de 05.10.88, reconheceu o concubinato puro como uma forma de constituição familiar, sob o nome de união estável. 
Sob a influência da nova Constituição, a união estável foi regulada pela Lei $n$. 8.971, de 29.12.94, protegendo os direitos do companheiro, concedendo-lhes alimentos e herança; atualmente projetos estão tramitando, na Câmara dos Deputados e no Senado Federal ( as duas Casas que constituem o Congresso Nacional), para a regulamentação do Estatuto dos Concubinos.

Sobre a união estável, a liberdade dos companheiros é maior, porque eles vivem como se fossem marido e mulher, mas, na realidade, eles não o são. Não há estado conjugal mas, simplesmente, uma vida familiar ou concubinato. Por outro lado, destaca-se que, sob o prisma psicológico, atualmente, as pessoas casadas, só religiosamente, sem que tenha existido registro de seu casamento, embora se sintam casadas, vivem sob o regime da união estável.

É necessário que haja possibilidade de considerar a união estável como uma espécie nova de casamento de fato, o que eu proponho.

Assim, para mim, já com esse espírito "de iure constituendo", o casamento de fato ou união estável é a convivência não-adulterina nem incestuosa, duradoura, pública e contínua, de um homem e de uma mulher, sem vínculo matrimonial, convivendo como se casados, sob o mesmo teto ou não, constituindo, conseqüentemente, sua família de fato.

\section{Abstract:}

The marriage implied, in the old times, in the religious celebration or, for the own interested parts, without any participation of the State.

In the Roman Law existed, particularly, the marriage with a celebration of religious character ("confarreatio"), the marriage by a simulate purchase of the woman ("coemptio"), the common law marriage, by the continuous possession ("usus"), the concubinage, having importance the family life as husband and wife, without marriage ("concubinatus") and the marriage among slaves ("contubernium").

Those configurations of family constitution remained in the Middle Age, reached the Brazilian Law, through the Kingdom Ordinations, from Portugal, especially by the Fillipines Ordinations, from 1603. In those ones there were: a) the religious marriage; b) the clandestine (secret) marriage, also known as common law marriage or called marriage of "conhuçudos", in which the durable family life of the man and the woman, who were constituting a family, led them to the condition of being married; and c) the marriage by public assignment, in front of two witnesses.

With the edition, among us, of the Decree n. 181, from 1890, which established the Civil Law Marriage, with formal severity, almost more than one hundred years ago, the others forms of family constitution, that were being accepted by the Brazilian society, were no more acknowledged, as they were, by the government.

Also, how the divorce was prohibited, what lasted till the arrival of the Law n. 6.515, from 27.12.77, those who separated judiciously (at that time called separated "desquitados") lived in a pure common law marriage, that is, neither in an adulterine nor in an incestuous way. 
The common law marriage was today what we call pure common law marriage, as seen, and there is the impure common law marriage (incestuous or adulterine), that has been always condemned. Since then, the depreciative sense of the word concubinage extinguished, gradually, among us, as a reconquest, by our people, of the old common law marriage. This form of marriage lasts in several other countries as the "married on common law", in fourteen American States; in Scotland, with the same name; and in the Mexican State of Tamaulipas marriage by behavior ("casamiento por comportamiento").

The Federal Brazilian Constitution, from 05.10.88, recognized the pure concubinage, as a form of family constitution, under the name of steady union.

Under the atmosphere of the new Constitution, the steady union was regulated, by the Law n. 8.971, from 29.12.94, taking care of the companions' rights concerning alimony and succession; presently projects are going through the proper channels, in the Deputy Chamber and the Federal Senate (two Legislative Houses that constitute the National Congress), for the regulation of the Statute of the Concubines.

On the stable union, the liberty of the companions is greater, because they live as if they were husband and wife, but, in reality, they are not. There is no conjugal estate, but simply, a family life or a concubinage.

On the other hand, it is important to stand out that, under the psychologic aspect, presently, the married people, who got married only in a religious way, with no wedding register, although they feel as being married, they live under the stable union regimen.

It is necessary that there is the possibility of considering the stable union like a new kind of common law marriage, that is what 1 propose.

This, for me, already with this spirit "de iure constituendo": the common law marriage or the stable union is the family life neither adulterine nor incestuous, durable, public and continuous of a man and a woman, without matrimonial entailment, and living as being married, under the same roof or not and, consequently, constituting their real family. 
Sumário:

1 Considerações iniciais

2 - Breves aspectos históricos

3 Causas do concubinato

4 Conceito e espécies de concubinato

5 Concubinato e sociedade de fato

6 Regulamentação do concubinato

7 - Constituição de 1988

8 - Orientação da Jurisprudência, após a Constituição de 1988

9 - Casamento de fato e união estável

10 Lei n. 8.971, de 29.12.1994

11 Meu entendimento.

\section{1 - Considerações Iniciais}

Foi aprovado, na Câmara dos Deputados, o Projeto de Lei n. 1.888, de 1991, de autoria da deputada Beth Azize, em que figurou como relator o deputado Edésio Passos, fundamentado, parcialmente, no Esboço de Anteprojeto de lei, às páginas 280 a 283, de meu livro Do Concubinato ao Casamento de Fato (Editora Cejup, Belém do Pará, $2^{\mathrm{a}}$ edição, 1987, 306 páginas).

Atualmente, esse mesmo Projeto de Lei encaminhou-se ao Senado Federal, tomando o n. 84, de 1994, tendo como relator o senador Wilson Martins. Este projeto, mais completo, resgatou artigos do meu aludido Esboço, que tinham sido retirados do Projeto originário, da Câmara dos Deputados.

Tudo, para que seja regulamentada a União Estável, prevista no $\S 3^{\circ}$ do art. 226 da Constituição Federal, como uma das formas de instituição da família brasileira.

\section{2 - Breves Aspectos Históricos}

$\mathrm{Na}$ antigüidade, a família era, em geral, constituída por meio de celebrações religiosas ou por meio de simples convivência.

No Direito Romano, a mulher passava a integrar a família de seu marido, pela conventio in manum, sujeitando-se à manus, que era o poder marital, por uma das seguintes formas de constituição familiar: a) pela confarreatio, que consistia em uma cerimônia religiosa, reservada ao patriciado, com excessivas 
formalidades, com a oferta a Jupiter de um pão de farinha (panis farreum), que os nubentes comiam, juntos, realizada perante dez testemunhas e perante o sacerdote de Júpiter (flamen Dialis); b) pela coemptio, casamento privativo dos plebeus, que implicava à venda simbólica da mulher ao marido, assemelhando-se, pela forma, à mancipatio; e c) pelo usus, que era o casamento pela convivência ininterrupta do homem e da mulher, por um ano, em estado possessório, que, automaticamente, fazia nascer o poder marital, a não ser que, em cada período de um ano, a mulher passasse três noites fora do lar conjugal (trinoctii usurpatio).

Além, dessas formas de casamento, existiu o concubinato, em Roma, regulamentado, de modo indireto, à época do imperador Augusto, pelas Lex Iulia e Papia Poppaea de maritandis ordinibus.

Embora tendo reprovado o concubinato, como forma de constituição de família, a Igreja Católica tolerou-o, quando não se cuidasse de união comprometedora do casamento ou quando incestuosa, até sua proibição pelo Concílio de Trento, em 1563.

Ressalte-se, em verdade, que a existência do casamento, nos moldes de antigamente, sem os formalismos exagerados de hoje, não possibilitava, praticamente, a formação familiar sob o modo concubinário.

Realmente, bastava que um homem convivesse com uma mulher, por algum tempo, como se casados, com ou sem celebração religiosa, para que se considerassem sob casamento. Isto, porque, nessa época, o concubinato puro, não adulterino nem incestuoso, que é utilizado, hoje, como modo de constituição de família, era o casamento de fato, provado por escritura pública ou por duas testemunhas.

Esse, o casamento de fato, que, sob a singela forma de convivência no lar, selava a união dos cônjuges, sob o pálio do Direito Natural.

O concubinato, portanto, existia somente adulterino, como concorrente e paralelamente ao casamento, de modo excepcional e desabonador da família.

Todavia, desrespeitando essa lei natural e simples, entendeu o legislador de criar formalismos ao casamento, criando-o de modo artificial, na lei, quando, em verdade, ele é um fato social, que a legislação deve regular, somente no tocante a seus efeitos, para impedir violações de direitos.

Assim, editou-se, no Brasil, o Decreto n. 181, de 24 de janeiro de 1890, que secularizou o casamento. A partir dele, o formalismo tomou conta da 
legislação brasileira, em matéria de casamento, reeditando-se o sistema no Código Civil.

Com isso, deixou o Estado brasileiro não-só de considerar o casamento de fato (por mera convivência duradoura dos cônjuges), bem como o casamento religioso, que, hoje, por si só, sem o posterior registro civil, é considerado concubinato. Não tem ele existência autônoma, independente, como antes desse Decreto de 1890.

\section{Causas do Concubinato}

A par desse sistema formal, com muitos óbices à separação, e a par das dificuldades ao registro do casamento religioso, surgiu, paralelamente, uma nova tendência de constituição de família, pelo concubinato, que existe com grande intensidade nos países latino-americanos.

Ressalte-se, como visto, e mais uma vez, que, entre nós, a falta de registro civil do casamento religioso, base secular de constituição de família, importa concubinato.

É certo, ainda, que, com o advento do progresso e a agitação nos centros urbanos, diminuíram, sobremaneira e paulatinamente, a tolerância e a compreensão dos problemas aflitivos dos casais, levando-os, nesse estado de coisas, aos desquites (hoje, separações judiciais).

Como crescesse o número de desquites, era preciso que se possibilitasse a existência do divórcio, pela reforma constitucional, que só ocorreu em meados de 1977.

Embora a sociedade brasileira reprovasse o concubinato, também como forma de constituição familiar, no começo do século, o certo é que, com esse número crescente de desquitados, impossibilitados de se casarem, eles constituíram suas novas famílias, à margem da proteção legal, cumprindo o desígnio da lei natural de que o homem é animal gregário e necessita dessa convivência no lar.

Quando surgiu a lei do divórcio, a par de nova filosofia liberal do povo, já a sociedade acostumara-se à família concubinária, que preenche, atualmente, grande espaço de nossa sociedade, com problemas seriíssimos, que necessitam de cuidados legislativos. 


\section{Conceito e Espécies de Concubinato}

Todavia, neste passo, é indispensável que se conceitue o concubinato, por suas espécies, para diferenciá-las, devidamente.

Em sentido etimológico, concubinatus, do verbo concumbere ou concubare (derivado do grego), significava, então, mancebia, abarregamento, amasiamento.

Apresenta-se esse vocábulo, atualmente, com dois sentidos: amplo e estrito. Pelo sentido amplo ou lato, significa todo e qualquer relacionamento sexual livre; pelo sentido estrito, é a união duradoura, constituindo a sociedade familiar de fato, com affectio societatis, respeito e lealdade recíprocos.

Como se pode aquilatar, esse sentido amplo compreende, inclusive, a concubinagem, com relacionamentos reprováveis, tal, por exemplo, o adulterino, que leva uma pessoa casada a conviver, concubinariamente, em concorrência com sua vida conjugal.

Daí a necessidade de fixar-se o conceito de concubinato, em sua significação estrita, com fundamento no art. 1.363 do Código Civil, onde se assegura que a sociedade de fato nasce do somatório recíproco de esforços, pessoais ou materiais, para a obtenção de fins comuns.

À falta de outro dispositivo legal, mais específico, é nesse que se encontra a base da constituição da família de fato, que se mostra pela coabitação dos concubinos, como se casados fossem, presos pela affectio societatis, com a responsabilidade de provisão do lar pelo concubino, com o auxílio de sua mulher, cuidando ambos de sua prole.

Por isso que nenhuma sociedade pode existir sem a colaboração e a lealdade dos sócios.

Com esses dados e elementos, é possível, agora, conceituar o concubinato, abrangendo todas as suas espécies, como a união estável, duradoura, pública e contínua, de um homem e de uma mulher, não ligados por vínculo matrimonial ou concubinário, mas convivendo como se casados, sob o mesmo teto ou não, constituindo, assim, sua família de fato.

Desses elementos surgem as espécies de concubinato: puro e impuro.

É puro o concubinato, quando se constitui a família de fato, sem qualquer detrimento da família legítima ou de outra família de fato (este poderá rotular-se, também, de concubinato leal). Assim, ocorre, por exemplo, quando coabitam solteiros, viúvos e separados judicialmente, sob essa forma familiar. 
Impuro é o concubinato, se for adulterino, incestuoso ou desleal, como, respectivamente, o de um homem casado, que mantenha, paralelamente a seu lar, outro de fato; o de um pai com sua filha; e o de um concubino formando um outro concubinato.

Ressalte-se, neste passo, que, segundo meu entendimento, se o concubinato for adulterino ou desleal, mas o concubino faltoso estiver separado de fato de seu cônjuge ou de seu concubino anterior, cessará a adulterinidade ou a deslealdade, tornando-se puro seu concubinato.

Entendo que o concubinato puro ou concubinato simplesmente, ou união estável, na expressão atual de nossa Constituição, deve merecer, por parte dos Poderes Públicos, completa proteção; diferentemente do que deve suceder com o concubinato impuro ou concubinagem. Aduz-se que deste último não devem, em geral, ser protegidos seus efeitos, a não ser ao concubino de boa-fé, como acontece analogamente, com o casamento putativo e para evitar locupletamento indevido, quando a concubina, mesmo em adultério, aumenta o patrimônio do concubino casado.

\section{Concubinato e Sociedade de Fato}

Nossas doutrina e jurisprudência têm diferenciado a situação concubinária da sociedade de fato.

Realmente, a par do concubinato, vislumbrado em conceito já expendido, a comprovação da existência de sociedade de fato, patrimonial, entre os concubinos, é exigida pelo Supremo Tribunal Federal, pelo princípio sumulado sob n. 380 , para que se possibilite a dissolução judicial societária, com a partilha dos bens adquiridos pelo esforço comum.

Em apoio a essa súmula, têm entendido nossos Tribunais que o simples concubinato não gera direitos ao patrimônio do companheiro, sendo indispensável a prova para formação da sociedade de fato, com a efetiva colaboração econômica ou financeira dos concubinos, a realização de seu patrimônio comum.

Em que pese esse posicionamento de torrencial jurisprudência, entendo que, sendo o concubinato puro, união estável, basta a convivência concubinária, para que seja de admitir-se o condomínio. Neste caso, deve presumirse o esforço comum dos concubinos, pois não se uniram eles sob mera sociedade de fato, em qualquer empresa em que se vislumbre interesse meramente econômico, 
mas com o propósito de constituírem sua família. Esta última posição encontra respaldo em alguns acórdãos de nossos Tribunais.

Mas esse apoio à relação concubinária pura, que pretendo, deve ser retirado quanto ao concubinato impuro ou desleal; nesse caso deve ser exigida prova da aquisição patrimonial.

Entretanto, a atual súmula 380, citada, não diferencia entre as espécies de concubinato, exigindo essa participação comum, na aquisição proprietária, tanto numa quanto noutra espécie de concubinato. E, exigindo essa participação efetiva, de cunho econômico, a mesma súmula iguala a sociedade concubinária com outra qualquer, alheia aos desígnios familiares, negando o cunho de contribuição espiritual, que existe no lar.

\section{6 - Regulamentação do Concubinato}

É certo que a família de fato vive em maior clima de liberdade, do que a família de direito.

Todavia, a excessiva liberdade, em Direito, é muito perigosa, pois acaba por escravizar o mais fraco. Tudo, porque essa liberdade não pode ser totalmente desapegada de regulamentação, há que ser condicionada, pois ela termina, onde outra começa.

Assim, o Estado tem interesse em proteger as pessoas, evitando lesões de direito.

No fundo, o amor que liga os conviventes, ao primeiro impacto da união, é como a afeição dos sócios em uma empresa qualquer: pode acabar. Entretanto, quando uma sociedade civil ou comercial termina, não é o mesmo que o findar de uma sociedade de família. Esta é mais apegada a regras morais e religiosas, ao Direito Natural, devendo ter uma proteção maior, no âmbito do Direito de Familia, para que se respeite a célula, onde, no mais das vezes, com o nascimento de filhos, grava-se a natureza pela descendência, contrariando qualquer reprovação, que possa existir contra essa situação fática.

$\mathrm{Na}$ sociedade familiar de fato, como na de direito, os interesses são, preponderantemente, de cunho pessoal e imaterial. Isto, sem se cogitar do interesse maior do Estado, em preservar sua própria existência, mantendo no lar, as famílias, em relativo estado de felicidade e de segurança financeira. 
Porém, ao lado dessa liberdade convivencial, impõe-se a responsabilidade, para que, em nome daquela, não cresça demais o direito de um concubino, a ponto de lesar o do outro.

A família de fato não pode viver sob um clima de liberdade sem responsabilidade, tanto que, mesmo sem estar regulamentada, legalmente, em um só todo, já algumas normas existem a seu respeito, talhadas na lei, na jurisprudência e na doutrina.

Não se pode, em sã consciência, admitir que o regramento de conduta, na família de fato, seja inibidora da liberdade, porque, em Direito, cuida-se da liberdade jurídica, que vive no complexo do relacionamento humano, com as limitações necessárias.

Realmente, se é lícito que duas pessoas vivam como marido e mulher, sem serem casadas, não há que se admitir que, em caso de abandono ou de falecimento, bens fiquem em nome de uma delas, embora, por justiça, pertençam a ambos. Essa liberdade seria escravizante a possibilitar lesão, enriquecimento ilícito, o que é incompatível com o pensamento jurídico. O Estado há que intervir nessas situações, sendo melhor que o faça antes, regulamentando a matéria relativa à família de fato. Essa regulamentação, pelo Estatuto da União Estável, que venho propondo, deve mantê-la em sua forma natural, preservando-se a liberdade dos conviventes, mas sob clima de responsabilidade, para que exista segurança, em caso de lesão. Esta deve ser, sempre, prevista, para ser repelida.

Esse é o meu lema, para a regulamentação da união estável: Liberdade com Responsabilidade.

\section{Constituição de 1988}

A Constituição de 1988 , pelo $\S 3^{\circ}$ de seu art. 226, reconheceu o concubinato puro, não-adulterino nem incestuoso, como forma de constituição de família, como instituto, portanto, de Direito de Família.

Houve, por bem, ainda, o legislador constituinte substituir a palavra concubinato, pela expressão união estável, para inaugurar nova era de compreensão aos conviventes, respeitando seus direitos e sua sociedade de fato, que sempre existiu, antes do Decreto n. 181, de 1890, sob forma de casamento de fato ou presumido.

Por outro lado, entretanto, não estendeu essa mesma Constituição ao casamento religioso, como entendo correto, os efeitos do casamento civil, para 
recuperar sua antiga dignidade, ante o Estado. Limita-se ela, por seu art. 226, $\S 2^{\circ}$, a dizer, do mesmo modo que a anterior, que "o casamento religioso tem efeito civil, nos termos da lei". Esta, entretanto (Lei n. 1.110, de 23 de maio de 1950), só admite tal efeito quando pré ou pós-existe a habilitação para o casamento civil.

Assim, tanto o casamento civil, quanto o religioso, com suas formalidades próprias, devem existir, no meu entender, automática e independentemente.

A união estável precisa ser regulamentada, para que não existam abusos entre os conviventes, que devem ser livres na convivência, mas responsáveis.

8 - Orientação da Jurisprudência, Após a Constituição de 1988

Antes de editada a Constituição Federal de 5.10.88, e mais remotamente, a jurisprudência negava quaisquer direito decorrentes da relação concubinária.

Depois, passou a jurisprudência a conceder indenização à concubina, por serviços domésticos prestados a seu companheiro.

Finalmente, com fundamento, dentre outros, no art. 1.363 do Código Civil, editou-se a Súmula 380 do Supremo Tribunal Federal, já citada. Por ela, considerou-se, de um lado, o concubinato; de outro, a sociedade de fato entre concubinos.

Como visto, referido princípio sumulado criou, em nosso Direito de Família, a "teoria da sociedade de fato", exemplo do que ocorreu na jurisprudência francesa.

Desse modo, não bastava a prova da vida concubinária pura, mas a existência da sociedade de fato entre os concubinos, para justificar-se a partilha de seus bens.

O intuito foi, mesmo, de mostrar a necessidade de uma participação extraconcubinária, na aquisição patrimonial, a título oneroso (não-gratuito). Caso contrário, não haveria de fazer-se essa diferenciação entre sociedade concubinária e de fato, pois esta última pode ocorrer independentemente de relação familiar, com o somatório de esforços e/ou recursos para a obtenção de fins comuns, numa sociedade civil ou comercial.

Malgrado esse entendimento da necessidade de colaboração da concubina, para o aumento do patrimônio do casal concubinário, com uma visão 
muito mais econômica do que pessoal, a Constituição Federal de 1988 contribuiu para uma interpretação mais justa nas relações concubinárias.

Assim, o enunciado da Súmula 380 do Supremo Tribunal Federal, com a evolução jurisprudencial ocorrida nessa mais Alta Corte de Justiça, entendeu-se como harmonizado com a orientação consagrada pelo Supremo Tribunal de Justiça, conforme se percebe por julgados deste, desde sua instalação, que se deu por obra do legislador constituinte. Destaque-se que, por essa evolução, se começou a admitir a contribuição indireta para a formação do patrimônio dos concubinos.

Realmente, assentou a $3^{\text {a }}$ Turma do Superior Tribunal de Justiça, 18.10.94, sendo relator o ministro Cláudio Santos (JSTJ e TRF-Lex 68/77): “ $a$ concubina faz jus à partilha de bens, se demonstrada sua contribuição para a formação do patrimônio, não se exigindo a participação direta. Compreensão que se harmoniza com o enunciado n. 380 do egrégio STF"

Desse modo, malgrado decisão do Supremo Tribunal Federal, por sua $2^{\mathrm{a}}$ Turma, em 25.8.81, sendo relator o ministro Moreira Alves (RT 553/261: ver também orientação, nesse sentido, do STF, in RTS 117/1.264; no STJ, na mesma tecla, destaca-se decisão isolada no RE 5.202, relator ministro Barros Monteiro), no sentido de que, em sociedade de fato entre concubinos, a concubina deve provar que, "com capital ou com trabalho, contribuiu para a aquisição dos bens pelo concubino durante o concubinato" e que não se deve cogitar de "aspectos pessoais e espirituais da convivência more uxorio" é perfeitamente possível, também pela própria evolução jurisprudencial de nossa Corte Suprema, admitir-se a "contribuição indireta da ex-companheira" no amealhar desse patrimônio, como reconhecido no decisório anteriormente citado. Pode, assim, essa contribuição consistir "na realização das tarefas necessárias ao regular gerenciamento da casa, ai incluida a prestação de serviços domésticos" "diminuição de despesas (economia) proporcionada pela execução das atividades de cunho doméstico pela ex-companheira" (REsp 38.657-SP, relator ministro Sálvio de Figueiredo, j. em 22.3.94).

Acentuou, ainda, nesse sentido, a mesma $3^{\text {a }}$ Turma do Superior Tribunal de Justiça, em 27.3.90, sendo relator o ministro Eduardo Ribeiro (RSTJ 9/361: no mesmo diapasão, REsp 483-RJ, $3^{\mathrm{a}}$ Turma, relator ministro Nilson Naves, DJ 9.10.90, in JSTJ e TRF-Lex 20/62-75; REsp 45.886-SP, $4^{\text {a }}$ Turma, relator ministro Athos Carneiro, DJ 24.2.92), que a contribuição indireta, pela concubina, "ainda que eventualmente restrita ao trabalho doméstico, poderá ser o bastante" 
Para que exista sociedade de fato, não há necessidade de que contribua a concubina "com a entrega de dinheiro ao concubino; admite-se para tanto que a sua colaboração possa decorrer das próprias atividades exercidas no recesso do lar (administração da casa, criação e educação dos filhos)" julgou a $4^{\text {a }}$ Turma do Superior Tribunal de Justiça, em 9.8.94, sendo relator o ministro Barros Monteiro (JSTJ e TRF-Lex 67/55).

Destaque-se, neste ponto, importante decisão do Superior Tribunal de Justiça, de 21.8.90, por sua $3^{\mathrm{a}}$ Turma, sendo relator o ministro Cláudio Santos (AASP 1.766, de 28.10 a 3.11.92, pp. 407 a 414) em que se reconheceu a "contribuição indireta para a formação do patrimônio do casal" e a "inexistência de dissídio com a Súmula n. 380/STF", com a conseqüente partilha de bens entre os concubinos.

Nesse julgado, vê-se, nítida, a preocupação do ministro relator de declarar sua conviç̧ão de que "nesta Corte, causas como estas, que envolvam a aplicação da Súmula n. 380, certamente hão de exigir maiores reflexões sobre a sua manutenção ou não, considerando-se, principalmente, as avançadas idéias a respeito da família traduzidas no verbo da nova Constituição da República, de certa forma fiel à realidade social brasileira"

Bem ponderou o douto ministro que, do enunciado da Súmula n.380/STF, "a grande discussão levada aos tribunais constituiu em saber qual é o alcance que deverá ser dado, pela jurisprudência à expressão esforço comum" E, após citar várias decisões do Supremo Tribunal Federal (RTJ 75/936, RE 81.012GB, j. em 1.3.75, relator ministro Moreira Alves; RTJ 101/323, RE 93.644, $2^{\mathrm{a}}$ Turma, j. em 25.8.81; RE 91.120, relator ministro Cordeiro Guerra, não-publicado na $R T J$; RE 91.806, in RTJ 96/866, relator ministro Décio Miranda), concluiu que o entendimento dessa Corte Suprema é o de que o simples concubinato não gera direitos ao matrimônio do companheiro, devendo ser comprovada sociedade de fato e a participação, "com capital ou com trabalho", na aquisição dos bens partilháveis, de natureza econômica.

Nessa excelente pesquisa, quanto a esse entendimento de nossa Corte Suprema, aponta o mesmo ministro Cláudio Santos, em seqüência, que "apenas o ministro Leitão de Abreu se posicionou favorável à presunção da sociedade de fato, quando provada a vida more uxorio admitindo, em conseqüência, o direito à partilha dos bens adquiridos durante o concubinato (RT 540/219)" 
Mencionam-se, ainda, nesse acórdão sob análise, decisão da $1^{\text {a }}$ Câmara Cível do Tribunal de Justiça do Estado do Rio de Janeiro, na Apelação Cível n. 3.600/88, sendo relator o desembargador Carlos Alberto Menezes Direito, em que se reconheceu a união estável acolhida, constitucionalmente, como entidade familiar, sendo certo que, provada essa união, "pela longa convivência comum é cabível a meação dos bens adquiridos na constância desta"

Lembra, então, nesse passo, o ministro Cláudio Santos, que foi relator desse último citado caso. Destacando: "o tema em si, não foi abordado, eis que não conhecido o recurso, porém em meu voto fiz as seguintes considerações, inclusive transcrevendo trechos do brilhante voto do relator na instância ordinária: 'no que tange à contrariedade ao art. 1.363 do Código Civil, a versar, sobre a celebração do contrato de sociedade, não demonstrada está a violação, tanto mais que não cogitou a decisão desse tipo de sociedade mas sim dos efeitos da união estável, com a aparência de casamento' Efetivamente, é a seguinte a fundamentação do acórdão, na lavra do desembargador Carlos Alberto Menezes Direito: 'é certo que a interpretação construtiva que buscou escólios no art. 1.363 do Código Civil, tende necessariamente a encontrar amparo no fato natural da vida em comum, deslocando-se do cenário meramente econômico' Como anota Álvaro Villaça Azevedo, litteris: 'mesmo a admitir-se, com a citada Súmula n. 380, que é indispensável o 'esforço comum' dos concubinos nessa formação de seu patrimônio, há que entender-se esse esforço em sentido amplo, pois, nem sempre ele resulta de natureza econômica, podendo implicar estreita colaboração de ordem pessoal, às vezes de muito maior valia' (cfr. Do Concubinato ao Casamento de Fato, CEJUP, $2^{a}$ ed., p. 80)"

Muitos outros julgados, além dos já citados, vêm surgindo sem a exigência do exercício do trabalho remunerado da companheira, ao tempo da aquisição patrimonial pelo companheiro, como assentado no REsp 361-RJ (DJ $30.10 .89,4^{\mathrm{a}}$ Turma, relator ministro Fontes de Alencar).

Tenha-se presente exemplar acórdão da $2^{\mathrm{a}}$ Câmara Civil do Tribunal de Justiça do Estado de São Paulo, em 17.12.91, sendo relator o desembargador Cezar Peluso (AASP 1.765, de 21 a 27.10.92, p. 396), em que se entendeu que, "adquirindo patrimônio durante a união estável, sujeita aos princípios jurídicos do Direito da Família, têm os concubinos, ou ex-concubinos, direito à partilha, ainda que a contribuição de um deles, em geral da mulher, não haja sido direta, ou pecuniária, se não indireta, a qual tanto pode estar na direção educacional dos 
filhos, no trabalho doméstico, ou em serviços materiais doutra ordem, como na ajuda em termos de afeto, estímulo e amparo psicológico"

Como restou evidenciado, até este ponto de minha exposição há um ano e meio, aproximadamente, da edição do texto constitucional vigente, em meu citado livro Do Concubinato ao Casamento de Fato, defendia eu a necessidade de inserir-se o concubinato puro sob proteção da Lei Maior e de admitir-se a presunção de condomínio dos bens adquiridos onerosamente na constância do concubinato pelo esforço dos concubinos, fosse de caráter econômico (material) ou pessoal (imaterial, espiritual).

Ressalta-se, neste passo, o texto do art. 10, proposto em meu esboço de Anteprojeto: "Patrimônio - Os bens móveis e imóveis, adquiridos por um ou por outro ou por ambos os concubinos, na constância do concubinato e a título oneroso, são considerados fruto do trabalho e da colaboração comum, passando a pertencer a ambos, em condomínio, e em partes iguais, salvo estipulação contratual escrita, em contrário"

Com a edição da recente lei, que instituiu, entre nós, o Estatuto dos Concubinos, minha posição doutrinária fica consolidada, não tendo mais razão de ser, em matéria de Direito de Família, a diferença entre concubinato puro e sociedade de fato, pois a simples convivência concubinária pura, nos moldes dessa novel legislação, assegura aos conviventes o direito de propriedade, em igualdade de condições, sobre os bens adquiridos, onerosamente na constância do concubinato, salvo prova escrita em contrário.

\section{9 - Casamento de Fato e União Estável}

Como visto, tanto a união estável quanto o antigo casamento de fato nascem, espontânea e naturalmente, na sociedade, isentos de formalismos.

Em verdade, a união estável de hoje, nada mais é, na sua aparência, do que $o$ antigo casamento de fato ou presumido.

Entretanto, no casamento de fato, os conviventes sentem-se casados, como esposos, porque são casados, tal como o casamento da common law, que existe hoje em alguns Estados americanos, o por comportamento do Estado de Tamaulipas, no México, o da Escócia e o casamento de fato ou clandestino admitido pelas Ordenações Filipinas, até o advento do aludido Decreto n. 181, de 1890, que instituiu, entre nós, o casamento civil. 
Desse modo, pelo casamento de fato, desde o início da convivência, sem quaisquer formalidades de celebração, ainda que religiosa, existe o casamento presumido.

$\mathrm{Na}$ união estável, a liberdade dos conviventes é maior, porque vivem como se fossem marido e mulher, mas sem o serem, em verdade. Não existe o estado conjugal, mas, meramente, o convivencial ou concubinário.

Por outro lado, destaque-se que, sob o prisma psicológico, atualmente, as pessoas casadas, só religiosamente, sem que tenha existido registro de seu casamento, embora se sintam casadas, vivem sob o regime da união estável.

$$
10 \text { - Lei n. 8.971, de 29.12.1994 }
$$

Muitos têm considerado como Estatuto dos Concubinos o preceituado na Lei n. 8.971/94, que assegura aos concubinos direitos a alimentos e à sucessão.

Todavia, essa lei não apresenta características de um Estatuto, pois nada faz além de, simplesmente, conceder aos concubinos direitos que são concedidos aos cônjuges.

Com a edição da Lei n. 8.971, de 29.12.94, regulou-se o "direito dos companheiros a alimentos e à sucessão"

Antes dessa lei e mesmo antes do advento da Constituição Federal de 1988, a jurisprudência vinha negando, sistematicamente, alimentos aos conviventes, a não ser quando por estes contratados.

Desse modo, tem sido julgado que, sem prova da obrigação, não há como embasar pedido de alimentos entre companheiros (RTJ 80/119; RT 595/270, 516/58 e 459/187); que, sem contrato com obrigação alimentar prevista, não é de admitir-se pensionamento ( $R T$ 594/48; 557/64 e RJTJSP-Lex 138/42, 132/46, 119/26 e 51/30).

O Supremo Tribunal Federal firmou entendimento de que " $a$ sociedade de fato se situa no terreno do direito das obrigações, razão por que não dão margem a ela aspectos pessoais e espirituais da convivência "more uxorio' " (RTJ 101/323; outras decisões no mesmo sentido, in RJTJSP-Lex 129/36, 113/469).

Embora entenda que a matéria concubinária pertença ao âmbito do Direito de Família, não fui eu favorável ao direito alimentar entre conviventes, no meu Estatuto dos Concubinos (art. $4^{\circ}$ ) (veja p. 16), a não ser quando expressamente contratados, conforme reconheceu unanimemente, a $1^{a}$ Câmara Civil do Tribunal de Justiça do Estado de São Paulo, em 25.05.90, sendo relator o desembargador Roque 
Komatsu (RJTJSP-Lex 131/60), com suporte, também, nas lições do professor Yussef Said Cahali.

A jurisprudência vem decidindo que a norma constitucional do $\S 3^{\circ}$ do art. 226 criou função para o Estado e não para a relação concubinária, não tendo equiparado o concubinato ao casamento (RT 675/107, 674/107, 653/105; RJTJSPLex 126/45).

Realmente, não houve a aludida equiparação, pois a união estável foi reconhecida, como integrante do Direito de Família, como uma das formas de constituição familiar, nos moldes como foi escolhida pela sociedade. Em verdade, a união estável ou o concubinato puro foi o ressurgimento do casamento de fato, arraigado no costume popular.

A lei sob estudo, criou entre os conviventes o direito material a alimentos, pondo termo às controvérsias existentes quando de sua edição.

Ressalte-se, neste ponto, que o então juiz Sérgio Gischkow Pereira, do Tribunal da Alçada do Rio Grande do Sul ("A união estável e os alimentos" artigo in RT 657/20), hoje desembargador, entende que, tendo a Constituição Federal de 1988 evidenciado que o Estatuto protege a união estável, o Poder Judiciário é igualmente Estado, devendo conceder o direito alimentar em matéria concubinária. E, como visto, desde a edição o texto constitucional.

Pondera em bom raciocínio esse magistrado: "se a relação concubinária provoca perda de alimentos percebidos em decorrência de anterior casamento, como é pacífico em nosso País, obviamente esta linha de pensamento só pode partir do pressuposto da existência de um dever alimentar entre os concubinos!"

Entretanto entendeu a $1^{\text {a }}$ Câmara do Tribunal de Justiça do Estado de Minas Gerais, em 2.10.84, sendo relator o desembargador Valle da Fonseca (RT 597/189), que não se justifica que a mulher, hoje com direitos iguais ao homem em condições de trabalhar para manter-se, peça pensão a seu marido. Bem ponderou em referido julgado, que, ante o art. 19 da Lei do Divórcio, n. 6.515 de 26.12 .77 , duas são as situações em que um cônjuge deve prestar alimentos ao outro: ser responsável pela separação do casal e o cônjuge inocente necessita de alimentos.

Também a $2^{\mathrm{a}}$ Câmara do Tribunal de Justiça do Estado de São Paulo, em 29.8.89, sendo relator o desembargador Walter Moraes (RT 647/86) bem decidiu que o pedido de alimentos "é inadmissível por incompatibilidade com a regra constitucional da igualdade absoluta" 
$\mathrm{O}$ art. $1^{\circ}$ da Lei n. 8.971/94 concede à companheira ou companheiro, na união estável (concubinato puro), após a convivência de cinco anos ou a existência de prole, o direito a alimentos, nos moldes da Lei n. 5.478, de 25.7.68, "enquanto não constituir nova união e desde que prove a necessidade"

Reafirmo que, em meu Esboço de Anteprojeto de "Estatuto dos Concubinos", não fui favorável à concessão de direito a alimentos entre conviventes, a não ser quando contratados por escrito.

Acontece que já existia uma ligeira tendência jurisprudencial à concessão desses alimentos, após a Constituição de 1988: talvez, por esta, em seu art. $226 \S 3^{\circ}$ recomenda que a lei facilite a conversão da união estável em casamento. Isto, principalmente, nos Tribunais de Justiça do Estado do Rio Grande do Sul e do Rio de Janeiro (conferir RT 657/20 a 22 e AASP 1.602/210).

Desse modo, concedendo direito alimentar aos conviventes, reconhece a lei, sob cogitação, os mesmos direitos e deveres existentes entre os cônjuges, constantes da aludida Lei de Alimentos, n. 5.478, de 1968.

Todavia, entre os conviventes, esse direito-dever alimentar existe, tãosomente, após o decurso de prazo de cinco anos ou o nascimento de filho.Surge, assim, a dificuldade de comprovação do relacionamento concubinário, initio litis, já que de cunho eminentemente fático, de difícil comprovação por documentos.

Havendo prole, o casal concubinário consta da certidão de nascimento, como pais da criança. Na ausência de filhos, é possívei que exista prova documental da união estável, como a certidão de seu casamento religioso, sem efeitos civis. Os documentos indicadores dessa união são, por exemplo, contrato escrito de concubinato, contrato de locação, contrato de sociedade, carta, fotografia, nota fiscal com o endereço do casal, requerimento em juízo ou em repartições públicas, etc.

Caso o juiz não se convença dessa comprovação de vida concubinária ou tenha dúvidas quanto ao prazo de sua duração, poderá, a meu ver, para conceder alimentos provisórios, designar audiência de justificação prévia, ouvindo-se testemunhas (vizinhos, zeladores, vendedores de bairro de seu domicílio, etc. ).

Se a prova da convivência não puder ser obtida, liminarmente, não serão concedidos alimentos provisórios, devendo o feito seguir o rito ordinário.

O dispositivo sob análise estabelece que o postulante de alimentos comprove a necessidade destes, não sendo, portanto, automática a aquisição desse crédito alimentar. Estabelece, ainda, a causa de cessação desse pensionamento, com a constituição, pelo alimentado, de nova união, seja concubinária ou matrimonial. 
Porém, esse art. $1^{\circ}$ não menciona a hipótese de mau comportamento do convivente alimentado, que é prevista, corretamente, pela jurisprudência, como causa de perda da pensão alimentícia. Não é correto que o convivente, que se entregue a maus costumes, como à prostituição, por exemplo, continue a receber alimentos de seu companheiro.

Também não entendo que seja justo que o convivente culpado da rescisão do contrato concubinário, seja escrito ou não, possa pleitear alimentos do inocente.

A seu turno, o art. $2^{\circ}$ da lei sob comentário cuida do direito sucessório dos conviventes, nos parâmetros mencionados em seus três incisos. Os dois primeiros reeditam o preceituado no $\S 1^{\circ}$ do art. 1.611 do Código Civil, que trata desse direito, mas do cônjuge viúvo, que era casado sob o regime de bens diverso do da comunhão universal (usufruto vidual).

Assim, o concubino ou a concubina que sobreviver, enquanto não constituir nova união concubinária, terá direito ao usufruto da quarta parte dos bens do falecido, se houver filhos deste ou do casal concubinário. Esse usufruto corresponderá à metade desses bens, se não houver filhos, ainda que sobrevivam ascendentes.

Parece-me justo e importante realçar, neste passo, que não-só a constituição de nova união concubinária deverá fazer cessar o aludido direito de usufruto, mas também nova união matrimonial. No casamento em regime diverso do da comunhão universal, esse direito de usufruto do cônjuge sobrevivente perdura enquanto durar essa viuvez.

O que objetivou o legislador foi a proteção, em ambas as hipóteses, do cônjuge ou do concubino sobrevivente, por estar privado de seu cônjuge ou de seu companheiro.

Entendo não conveniente essa reafirmação, para os conviventes do aludido direito a usufruto, pois, na prática, ele estorva o direito dos herdeiros. Melhor seria tornar o convivente sobrevivo herdeiro, adquirindo sua parte na herança, concorrendo com os aludidos filhos loco fillae ou loco filii, conforme o caso (como filha ou filho), tal como acontecia com as esposas no Direito Romano da Lei das XII Tábuas (em 450 a.C.). Assim, por exemplo, o companheiro sobrevivente, concorrendo com dois filhos, receberia cota da herança correspondente a um terço, ficando cada qual com o seu, sem o obstáculo do usufruto, gravando direito dos filhos herdeiros. 
Também, porque entendo que não deva existir essa espécie de usufruto entre cônjuges. Correta, a meu ver, a posição assumida pelo Projeto do novo Código Civil, n. 634-B, de 1975 (aprovado pela Câmara dos Deputados, em 1984, n. 118, no Senado Federal), que, nos arts. 1.855 e 1.856, inciso I, concede quinhão hereditário ao cônjuge supérstite, nas hipóteses ali mencionadas: todavia, no inciso II deste último dispositivo legal, retorna concessão de usufruto da quarta parte da herança, "nos demais casos".

Do mesmo modo no art. 1.852 desse projeto, a ordem da vocação hereditária inclui o cônjuge sobrevivente concorrendo, nas situações que descreve, com os descendentes e com os ascendentes.

Todavia, a adoção completa do modelo romano está, mesmo, na Emenda n. 358 a esse dispositivo de pré-legislação, oferecida no Senado Federal pelo senador Nelson Carneiro, em 18.9.84, para ser incluída como parágrafo único do aludido art. 1.852 ou onde for conveniente, no seguinte teor: "a companheira do homem solteiro, separado judicialmente, divorciado ou viúvo, que em sua companhia tem estado nos cinco anos precedentes à sua morte ou de quem tenha prole, participará de sua sucessão nas condições seguintes:

I - Se concorrer com filhos comuns terá o direito a uma cota equivalente à que por lei é atribuída ao filho.

II - Se concorrer com descendentes do autor da herança dos quais não seja ascendente, tocar-lhe-á somente a metade do que couber a cada um daqueles.

III - Se concorrer com outros parentes sucessíveis terá direito à metade da herança.

IV - Não havendo parentes sucessíveis terá direito a dois terços da herança"

A inserir-se o texto da presente emenda senatorial no novo Código Civil, estarão revogados os dispositivos legais de caráter sucessório, constantes dos arts. $2^{\circ}$ e $3^{\circ}$ da comentada lei, que favorecem os concubinos.

Ressalto que todos os textos que estão programados nesse Projeto de novo Código Civil devam valer, em igualdade de condições, para o casamento e para o concubinato, impedindo que os concubinos tenham mais direitos do que as pessoas casadas.

Voltando à Lei n. 8.971/94, em plena vigência, cumpre notar que o inciso III de seu art. $2^{\circ}$, ainda sob cogitação, concede direito ao companheiro 
sobrevivente sobre a totalidade da herança do falecido, quando este não deixar descendentes e ascendentes.

Esse mesmo direito é concedido ao cônjuge sobrevivente, se, ao tempo da morte do outro, não estava dissolvida a sociedade conjugal.

Por sua vez, o art. $3^{\circ}$ da lei, sob foco, em caso de sucessão por morte, concede direito à metade dos bens adquiridos pelos concubinos, ao sobrevivente, quando esse patrimônio resultar de "atividade em que haja colaboração" deste último. Cuida-se, neste caso, portanto, de meação e não de herança.

Todavia, não esclarecendo sobre que espécie de colaboração deva considerar-se, acaba esse artigo por reeditar o preceituado na Súmula 380 do Supremo Tribunal Federal ("Comprovada a existência de sociedade de fato entre os concubinos, é cabivel a sua dissolução judicial, com a partilha do patrimônio adquirido pelo esforço comum"). Por essa mesma súmula exige-se a comprovação de sociedade de fato, entre os concubinos, e a prova da aquisição do seu patrimônio, por esforço comum.

Ante esse art. $3^{\circ}$. sob comentário, cogita-se da sucessão por morte de concubino, quando existem herdeiros necessários (descendentes ou ascendentes), situação em que, sobre a aludida herança, terá o concubino sobrevivente direito à metade do que ajudou a adquirir.

\section{Meu Entendimento}

Entendo que deveria voltar a existir o casamento religioso, só com celebração religiosa, ao lado do casamento civil, com os formalismos abrandados, inclusive no tocante à separação e ao divórcio.

Assim, com maior ou menor liberdade, teríamos o casamento sob todos os seus aspectos histórico-existenciais mais importantes.

A sociedade moderna está repelindo os excessos de formalismo, com tendência ao casamento simples, do passado.

O casamento, na antigüidade, sempre mostrou-se celebração religiosa ou das próprias partes interessadas, sem participação do Estado.

Assim, a celebração religiosa deve ter autonomia e ser reconhecida pelo Estado, por si só, independentemente de registro civil.

Ao lado desse casamento religioso, sempre existiu o casamento de fato, que corresponde ao casamento clandestino ou de conhuçudos, pela simples convivência como marido e mulher, que chegou até nós pelas Ordenações do Reino, até a edição do Decreto n. 181, de 1890, que criou os rigores de forma, hoje 
existentes, instituindo, há pouco mais de cem anos, o casamento civil. Antes, tudo era natural em matéria de casamento, como sempre foi no passado.

Desse modo; pelas mesmas Ordenações existiam o casamento religioso, o clandestino (pela convivência, que corresponde ao concubinato puro, hoje união estável) e por escritura pública, com duas testemunhas.

A par dessas formas de constituição, existia o concubinato impuro (incestuoso ou adulterino), sempre condenado. Daí, o sentido pejorativo da palavra concubinato, que se apagou, paulatinamente, entre nós, como uma conquista, pelo nosso povo, do antigo casamento de fato.

O casamento civil imposto pelo Estado, em 1890, aniquilou todas as aludidas formas naturais de constituição de família, que, há aproximadamente 3.000 anos, vinham sendo praticadas.

A Constituição Federal, de 1988, abriu caminho à livre escolha popular de seu modo de convivência familiar, exemplificando as formas que podem ser escolhidas e resgatando a figura do casamento de fato, pelo reconhecimento da união estável.

Ainda que existiam modalidades matrimoniais, mencionadas na lei, pelo Estado, não pode este impedir que a sociedade se utilize das formas tradicionais de constituição familiar.

O poder maior é o do povo. O Estado deve regulamentar o que existe, impedindo lesões de direito.

Nesse clima saudável da nova Constituição Federal regulamentou-se o Estatuto dos Concubinos, pela comentada lei, fazendo justiça ao nosso povo, que vivia desnorteado, em um clima de liberdade selvagem, sem responsabilidades que vinham sendo sanadas, com muito esforço, pelos nossos Tribunais.

A questão dos concubinos será tratada mais profundamente no livro que estamos desenvolvendo Estatuto dos Concubinos, a ser lançado em breve pela Editora Jurídica Brasileira.

Para permitir ao leitor o confronto e a seqüência do que ocorreu, estou produzindo, a seguir, o meu esboço do anteprojeto, o projeto da Câmara dos Deputados, projeto do Senado, o último projeto modificado da Câmara dos Deputados e, finalmente, o texto da Lei n. 9.278, de 10 de maio de 1996. 
Proposta para regulamentação do concubinato (esboço de um anteprojeto)

Por Álvaro Villaça Azevedo

Estatuto dos Concubinos - Anteprojeto de Lei

\section{Capitulo I Conceito}

Art. 1. Concubinato é a união estável, prolongada, pública, contínua e permanente de um homem e de uma mulher, não ligados por vínculo matrimonial, mas convivendo como se casados, sob o mesmo teto ou não, constituindo, assim, sua família de fato.

\section{Capítulo II Espécies}

Seção I - Concubinato Puro

Art. $2 .^{\circ}$ Conceito $\mathrm{O}$ concubinato puro é a convivência não adulterina e nem incestuosa.

Art. 3. Considera-se, ainda, concubinato puro o que existir, após estar o concubino adúltero ou desleal separado de fato de seu cônjuge ou de seu outro concubino conforme o caso.

Art. $4 .^{\circ}$ - Direitos e Deveres São direitos e deveres recíprocos dos concubinos: a) lealdade; b) coabitação, ainda que com residências diferentes; c) assistência material e imaterial, sendo devidos alimentos se expressamente contratados, ao alimentando que deles necessitar.

Art. $5^{\circ}$ - São deveres de ambos os concubinos guardar, sustentar e educar seus filhos comuns.

Art. $6^{\circ}$ Fica assegurado que os direitos e os deveres dos concubinos são iguais.

Art. 7. Contrato Os concubinos podem programar sua convivência, por meio de contrato de concubinato, com estipulação de seus direitos e deveres, 
desde que, observados os preceitos desta lei, não afrontem as normas de ordem pública, atinentes ao casamento, aos bons costumes e aos princípios gerais de direito.

Art. 8. ${ }^{\circ}$ Querendo, poderão os concubinos estabelecer regras quanto à administração do patrimônio comum e a seu direito alimentar.

Art. 9. - Esse contrato, para valer contra terceiros, deverá ser levado ao Registro Civil da Circunscrição domiciliar de qualquer dos concubinos.

Art. 10 Patrimônio - Os bens móveis e imóveis, adquiridos por um ou por outro ou por ambos os concubinos, na constância do concubinato e a título oneroso, são considerados fruto do trabalho e da colaboração comum, passando a pertencer a ambos, em condomínio, e em partes iguais, salvo estipulação contratual escrita, em contrário.

Art. 11 - Não será de admitir-se essa presunção, se a aquisição patrimonial ocorrer com o produto de bens adquiridos anteriormente ao início da união concubinária.

Art. 12 A administração do patrimônio comum dos concubinos compete a ambos, salvo disposição em contrário, por meio de contrato escrito.

Art. 13 - Filhos $\mathrm{O}$ concubinato cria, desde sua existência, a família de fato, presumindo-se dos concubinos os filhos havidos dessa união, que devem ser registrados em nome de ambos, voluntária ou judicialmente.

Art. 14 Toda a legislação de proteção aos filhos aplica-se, subsidiária e analogicamente, aos advindos das relações concubinárias.

Art. 15 Dissolução - A sociedade entre concubinos dissolver-se-á por morte de um deles, por rescisão ou resilição, devendo o concubino culpado, caso tenham sido contratados alimentos, por escrito, pagá-los ao inocente, se este deles necessitar.

Art. 16 - Ocorre rescisão, quando houver ruptura da sociedade, por conduta injuriosa de um a outro concubino ou quebra dos deveres constantes desta lei e do contrato, se existir.

Art. 17 Pela resilição unilateral, um dos concubinos denunciará a relação concubinária, por notificação ao outro, implicando essa denúncia, também, o afastamento do lar concubinário. 
Art. 18 - Pela resilição bilateral, os concubinos pð̃em termo ao concubinato, amigavelmente e por escrito, valendo entre os mesmos o que foi estipulado nesse acordo, desde que não contrarie o estatuído nesta lei. A separação de fato, pelos concubinos, também implica resilição bilateral.

Art. 19 - Outras Leis Passam a integrar o texto desta lei todas as situaçðes relativas ao concubinato, reconhecidas por outra legislação nacional, desde que não contrárias às estabelecidas nesta.

Seção II - Concubinato Impuro

Art. 20 Conceito O concubinato impuro é adulterino, quando paralelo ao casamento, e é desleal, quando existir concomitantemente com outro concubinato.

Art. 21 - Com a separação, ainda que de fato, do concubino adúltero de seu cônjuge e do desleal de seu outro concubino, conforme o caso, cessam as aludidas adulterinidade e deslealdade, bem como o dever de coabitação, iniciando-se o período do concubinato puro, aplicando-se as regras ao mesmo atinentes.

Art. 22 No concubinato impuro, deve ser comprovado, sempre, o esforço comum, a participação econômica efetiva do concubino, na aquisição de bens, para que exista direito condominial ou societário, no percentual que for.

\section{Capítulo III Disposição Geral}

Art. 23 - Toda a matéria relativa ao concubinato é da competência do Juízo das Varas de Família. 


\section{PROJETO NA CÂMARA DOS DEPUTADOS}

Projeto de Lei n. 1.888, de 1991, de autoria da Deputada Beth Azize.

Relator: Deputado Edésio Passos

(fundamentado, parcialmente, no Esboço de Anteprojeto do Professor Álvaro Villaça Azevedo, com a participação dos integrantes do CFEMEA).

Aprovado, com o seguinte texto, em 1994.

\section{O CONGRESSO NACIONAL decreta:}

Art. $1^{\circ}$ Considera-se união estável o concubinato more uxorio, público, contínuo e duradouro entre homem e mulher cuja relação não seja incestuosa ou adulterina.

Art. $2^{\circ}$ - São direitos e deveres iguais dos conviventes:

I - respeito e consideração mútuos;

II - assistência moral e material recíproca;

III - guarda, sustento e educação dos filhos comuns.

Art. $3^{\circ}$ - Os conviventes poderão, por meio de contrato escrito, regular seus direitos e deveres, observados os preceitos desta lei, as normas de ordem pública atinentes ao casamento, os bons costumes e os princípios gerais de direito.

Art. $4^{\circ}$ - Para valer contra terceiros, o contrato referido no artigo anterior deverá ser averbado no competente Cartório de Registro Civil.

Art. $5^{\circ}$ - Os bens móveis e imóveis adquiridos por um ou por ambos os conviventes, na constância da união estável e a título oneroso, são considerados fruto do trabalho e da colaboração comum, passando a pertencer a ambos, em condomínio e em partes iguais, salvo estipulação contratual contrária em escrito.

$\S 1^{\circ}$ - Cessa a presunção do caput deste artigo se a aquisição patrimonial ocorrer com o produto de bens adquiridos anteriormente ao início da união.

$\S 2^{\circ}$ A administração do patrimônio comum dos conviventes compete a ambos, salvo estipulação contrária em contrato escrito.

Art. 6. ${ }^{\circ}$ - A união estável dissolver-se-á por vontade das partes, morte de um dos conviventes, rescisão ou denúncia do contrato por um dos conviventes. 
$\S 1^{\circ}$ Pela vontade das partes os conviventes põem termo à união estável, amigavelmente e por escrito, valendo entre os mesmos o que for estipulado no acordo, desde que não contrarie o estatuído nesta lei.

$\S 2^{\circ}$ Havendo contrato escrito averbado em cartório, qualquer dos conviventes deverá requerer a averbação do acordo de dissolução da união estável.

$\S 3^{\circ}$ Ocorre a rescisão quando houver ruptura da união estável por quebra dos deveres constantes desta lei e do contrato escrito, se houver.

$\S 4^{\circ}$ - A separação de fato dos conviventes implica denúncia do contrato, escrito ou verbal.

Art. $7^{\circ}$ Dissolvida a união estável por rescisão, a assistência material prevista nesta lei será prestada por um dos conviventes ao que dela necessitar, a título de alimentos.

Art. $8^{\circ}$ - Esta lei entra em vigor na data de sua publicação. 


\section{PROJETO NO SENADO}

Projeto de Lei n. 84 (substitutivo), 1994

Relator: Senador Wilson Martins

(resgatou artigos do Esboço do Professor Álvaro Villaça Azevedo do trabalho deste com o grupo CFEMA).

Em tramitação.

\section{O CONGRESSO NACIONAL decreta:}

Art. $1^{\circ}$ - É reconhecida como entidade familiar a convivência nãoadulterina nem incestuosa, duradoura, pública e contínua, de um homem e de uma mulher, estabelecida com objetivo de constituição de família.

Art. $2^{\circ}$ - São direitos e deveres iguais dos conviventes:

I - respeito e consideração mútuos;

II - assistência moral e material recíproca;

III guarda, sustento e educação dos filhos comuns.

Art. $3^{\circ}$ - Os conviventes poderão, por meio de contrato escrito, regular seus direitos e deveres, observados os preceitos desta lei, as normas de ordem pública atinentes ao casamento, os bons costumes e os princípios gerais de direito.

Art. $4^{\circ}$ - Para valer contra terceiros, o contrato referido no artigo anterior deverá se averbado no componente Cartório de Registro Civil e também no Cartório de Registro de Imóveis onde estiverem registrados imóveis pertencentes a um ou outro dos conviventes.

Art. $5^{\circ}$ Os bens móveis e imóveis adquiridos por um ou por ambos os conviventes, na constância da união estável e a título oneroso, são considerados fruto do trabalho e da colaboração comum, passando a pertencer a ambos, em condomínio e em partes iguais, salvo estipulação contratual contrária em escrito.

$\S 1^{\circ}$ - Cessa a presunção do caput deste artigo se a aquisição patrimonial ocorrer com o produto de bens adquiridos anteriormente ao início da união.

$\S 2^{\circ} \quad$ A administração do patrimônio comum dos conviventes compete a ambos, salvo estipulação contrária em contrato escrito. 
Art. $6^{\circ}$ A união estável dissolver-se-á por vontade das partes, morte de um dos conviventes, rescisão ou denúncia do contrato por um dos conviventes.

$\S 1^{\circ} \quad$ Pela vontade das partes os conviventes põem termo à união estável, amigavelmente e por escrito, valendo entre os mesmos o que for estipulado no acordo, desde que não contrarie o estatuído nesta lei.

$\S 2^{\circ} \quad$ Havendo contrato escrito averbado em cartório, qualquer dos conviventes deverá requerer a averbação do acordo de dissolução da união estável.

$\S 3^{\circ}$ - Ocorre a rescisão quando houver qualquer ruptura da união estável por quebra dos deveres constantes desta lei e do contrato escrito se houver.

$\S 4^{\circ}$ - A separação de fato dos conviventes implica denúncia do contrato, escrito ou verbal.

Art. $7^{\circ}$ - Dissolvia a união estável por rescisão, a assistência material prevista nesta lei será prestada por um dos conviventes ao que dela necessitar, a título de alimentos.

Parágrafo único Dissolvida a união estável por morte de um dos conviventes, o sobrevivente terá direito real de habitação, enquanto viver ou não constituir nova união ou casamento, relativamente ao imóvel destinado à residência da família.

Art. $8^{\circ}$ - Os conviventes poderão, de comum acordo e a qualquer tempo, requerer a conversão da união estável em casamento, por requerimento, ao Oficial do Registro Civil da Circunscrição de seu domicílio.

Art. $9^{\circ}$ - Toda a matéria relativa à união estável é de competência do juízo das Varas de Família, assegurando o segredo de justiça.

Art. 10 Esta lei entra em vigor na data de sua publicação.

Art. 11 - Revogam-se as disposições em contrário. 